\title{
Specific Cytogenetic Aberrations in Two Novel Human Prostatic Cell Lines Immortalized by Human Papillomavirus Type 18 DNA
}

\author{
Philip C. Weijerman, Ellen van Drunen, Josee J. König, Wilma Teubel, \\ Johannes C. Romijn, Fritz H. Schröder, and Anne Hagemeijer*
}

\begin{abstract}
Using chromosome banding and fluorescence in situ hybridization (FISH) with painting probes, sequential cytogenetic analysis was performed of two novel prostate cell lines, PZ-HPV-7 and CA-HPV-10, established by human papillomavirus (HPV) 18 DNA transformation. PZ-HPV-7 originates from a normal diploid prostate epithelial cell strain. PZ-HPV-7 progressed from an initial diploid to a hypertetraploid chromosome number with a relative gain of chromosomes 5 and 20 ( 7 to 8 copies each). Structural changes were limited; $3 p-(2$ copies ), 3q- (1 copy), and possibly a der(16p;12q). CA-HPV-10 originates from an epithelial cell strain derived from a high-grade human prostate cancer specimen, which showed several karyotypic abnormalities including an extra Y chromosome and double minutes (dmin). In early passage the karyotype of CA-HPV-10 appeared unstable with a decreasing number of cells exhibiting dmin. In late passage the dmin were replaced by a large homogeneously staining region (hsr) on 9p+ marker. The hsr was shown by FISH to be of chromosome 1 origin. The modal number was mainly hypertriploid (72, range 69 to 75). Loss of $Y$ was remarkable (0 to 1 copy). Consistent markers included two copies each of del(1)(q12q31) and der(9)t(1;9)(?;p22), and one der(11)t(4;11) (?;q21). HPV type 18 genomic integration sites were identified on $1 p$ for PZ-HPV-7 and on the $9 p+$ marker for CA$H P V-10$. In conclusion, both PZ-HPV-7 and CA-HPV-10 showed clonal cytogenetic changes. These two cell lines constitute a novel in vitro model to study the mechanisms involved in human prostate carcino-genesis. (C) Elsevier Science Inc., 1997
\end{abstract}

\section{INTRODUCTION}

During the last decade in Western countries, the apparent incidence of prostate cancer has shown a tremendous rise mainly because of improved diagnostic modalities, such as the tumor marker prostate-specific antigen [1]. In comparison, the age adjusted cancer-specific mortality has not increased significantly, suggesting that prostate cancers may be diagnosed in the latent stage and that the risk of over treatment should be considered [2]. Nevertheless, prostate carcinoma is one of the leading causes of cancer

From the Departments of Urology (P. C. W., J. J. K., W. T., J. C. R., F. H. S.) and Cell Biology and Genetics, (E. V. D., A. H.), Erasmus University Rotterdam, Rotterdam, The Netherlands.

Address reprint requests to: Dr. Philip C. Weijerman, Dijkzigt Academic Hospital, Department of Urology, Erasmus University Rotterdam, Dr. Molewaterplein 40, 3015 GD Rotterdam, The Netherlands.

${ }^{*}$ Current affiliation: Professor Anne Hagemeijer, Laboratory for Clinical Molecular Cytogenetics of Malignancies, Center for Human Genetics, Catholic University Leuven, Herestraat 49, B-3000 Leuven, Belgium.

Received October 30, 1996; accepted January 14, 1997. mortality in the male. Therefore, because of the uncertain behavior and heterogeneous nature of the disease, the establishment of methods to distinguish clinically insignificant from potentially lethal cancers has become the future challenge for prostate cancer research. The development of human models for prostate carcinogenesis may allow for the identification of specific tumorigenic features. Even with continuous progress [3], the possibilities to study primary cells from the human prostate epithelium are limited by their short lifespan in culture. In search for an in vitro model of human prostate carcinogenesis, we used HPV type 18 DNA to immortalize epithelial cell cultures. Two cell lines were established: PZ-HPV-7, an epithelial precursor cell derived from normal prostatic peripheral zone tissue, and CA-HPV-10, an epithelial precursor cell derived from a high-grade adenocarcinoma of the prostate [4].

Characteristic cytogenetic aberrations may shed some light on tumor specific mechanisms of oncogenesis. During the last decade, several chromosomal abnormalities have been associated with prostate adenocarcinoma. The findings of specific karyotypic features of adenocarcinoma specimens have been significant. Chrosomomal gains and 
losses as well as structural anomalies reported in prostate cancer include almost all human chromosomes, i.e., 1, 2, $3,5,6,7,8,9,10,13,14,15,16,17,18,22$, X, and Y [518]. Of these chromosomal anomalies some seem to predominate. Gains of chromosomes X and 7, and 8q may be involved in prostate cancer progression [11-17] . Among the most commonly deleted regions implicated in prostate cancer we find 8p [6-10,13-17], first suggested in 1988 by König et al. [19], 10q [5-8, 13, 17], 16q [5, 6, 13, 17], and also anomalies of the Y chromosome [7, 8, 10, 14-16]. Furthermore, linkage analysis of 91 high-risk prostate cancer families recently provided strong evidence of a major prostate cancer supsceptibility locus on chromosome 1 [18]. Interestingly, one of the newly established HPV transformed cell lines, CA-HPV-10, was derived from a human prostate cancer cell strain with several karyotypic abnormalities, including an extra Y chromosome and double minutes (dmin) [7].

In this study, we report on the sequential analysis of both prostate cell lines and a detailed characterization of CA-HPV-10 marker chromosomes using whole chromosome paints and site specific probes. The HPV integration sites were also investigated using fluorescence in situ hybridization (FISH) methodology.

\section{MATERIALS AND METHODS}

\section{Cell Lines}

As reported previously [4], plasmids containing the full genome of HPV type 18 incubated with lipofectin (BRL Life Technologies, Gaithersburg, MD) were used for immortalization of two primary epithelial human prostate cell strains, LJpz and HSca. The two established cell lines-PZ-HPV-7, precursor LJpz derived from normal prostatic peripheral zone epithelium, and CA-HPV-10, precursor HSca derived from a high-grade (Gleason grade $4+4)$ prostatic adenocarcinoma specimen-were analyzed at different passages ranging from early (15 and 14) to late (99 and 94) numbers. Keratinocyte serum free media KSFM (GIBCO, Grand Island, NY), added with bovine pituitary extract (50 ug/ml), epidermal growth factor (5 ng/ $\mathrm{ml}$ ) and antibiotics was required for optimal growth.

\section{Cytogenetics}

Monolayers of in log phase growing cultures were incubated with colcemid $(0.015 \mu \mathrm{g} / \mathrm{ml})$ for $30 \mathrm{~min}$ to one hour. Longer incubation was required when limited numbers of rounded or mitotic cells were observed. Subsequently, metaphase cells were harvested by trypsinization, swollen in KCl-EGTA (0.075M), fixed in methanol:acetic acid (3:1), and spread on slides [19]. Chromosomes were identified by the R-banding and Q-banding technique using acridineorange and atebrine, respectively. At least 20 metaphases from each cell line were karyotyped.

\section{Fluorescence in Situ Hybridization (FISH)}

The DNA probes were labeled with Biotin-16-dUTP by standard nick translation, precipitated, and resuspended in hybridization mixture (50\% formamide, $10 \%$ dextran sulfate in $2 \times$ SSCP) with $50 \mu \mathrm{g}$ salmon sperm DNA and $50 \mu \mathrm{g}$ yeast t-RNA when competitive hybridization was necessary. The probe concentration was as follows: $0.5 \mathrm{ng} /$ $\mu \mathrm{l}$ for centromeric probes, $7.5 \mathrm{ng} / \mu \mathrm{l}$ for the HPV probe, and $10 \mathrm{ng} / \mu \mathrm{l}$ for chromosome-specific libraries. After probe denaturation $\left(4 \mathrm{~min}\right.$ at $72^{\circ} \mathrm{C}$ ), the repeat sequences were allowed to preanneal with $10 \mu \mathrm{g}$ Cot-1 DNA for 1 hour at $37^{\circ} \mathrm{C}$. Metaphase spreads on glass were pretreated with RNAse and $0.2 \%$ pepsin $(0.01 \mathrm{~N} \mathrm{HCl})$, postfixed, and denatured at $72^{\circ} \mathrm{C}$ for $2.5 \mathrm{~min}$ in $70 \%$ formamide. Probes were hybridized overnight at $37^{\circ} \mathrm{C}$ in a humidified box. After washing, the hybridization sites were visualized by immunochemistry using two layers of FITC in three steps with avidin-FITC, biotinylated goat-anti-avidin, and avidin-FITC. Results were observed in fluorescence using DAPI banding counterstaining and sometimes cohybridization with a known probe relevant for chromosome identification.

\section{Probes}

Various probes were used, single or in combination, in single or double color experiments.

HPV type 18. The full plasmid of HPV type 18 DNA cloned into pB322 (kindly received from Dr. E-M. de Villiers, Heidelberg, Germany) was used as a probe.

Whole chromosome paint. Chromosome specific libraries pBS 1 to 22, X, and Y, prepared and made available to us by J. Gray (University of California, San Francisco, USA). Separate experiments were performed using a commercially available chromosome 11 probe (Cambio LTD) as well as chromosomes 4 and 9 probes prepared by degenerate oligonucleotide-primed-polymerase chain reaction (DOP-PCR)-amplification [20].

Centromere probes. Probe PUC1.77 [21] for chromosome 1, pYAM11-39 [22] for 4, D8Z2 [23] for 8, pHUR98 [24] for 9, pLC11A [25] for 11, pHUR195 [24] for 16, L1.84 [26] for 18, and p3.4 [27] for 20 were used.

Gene loci specific probes. Site or gene loci-specific probe p1.79 (received from H. van Dekken, Rotterdam, The Netherlands) was used for identification of 1p36; oct 7a (received from R. de Zwart, Rotterdam, The Netherlands) was used for 1p32/2q23; ERCC3 [28] was used for 2q, 10.62/10.63; p16 tumor suppressor gene [29] was used for 9p21; and Cos-ABL-18 [30] was used for 9q34.

\section{RESULTS}

\section{Cytogenetic Analysis}

The PZ-HPV-7 cell line, precursor originating from a normal prostatic epithelial cell strain, was studied at passages 15, 38, and 99. PZ-HPV-7 progressed from an initial diploid chromosome number at passage 15 and 38 to a modal number of 106 chromosome, range 103 to 108. Analysis showed 3 to 5 copies of all chromosomes except $\mathrm{X}$ and $\mathrm{Y}$ ( 2 copies each) and chromosomes 5 and 20 (7 to 8 copies 
each). There were only a few structural changes: $3 p-(M 1$, 2 copies), 3q- (M2, 1 copy), and a third marker possibly a der(16p;12q)(M3). In Figure 1A the full karyotype is shown representing the late passage findings as described above.

The CA-HPV-10 parental cell strain HSca originated from a core of pure Gleason grade $4+4$ prostatic adenocarcinoma obtained from a radical prostatectomy specimen. The previously reported karyotype of HSca [7] showed several abnormalities including an extra $\mathrm{Y}$ chromosome and dmin. At passages 14 and 38, the karyotypes of cell line CA-HPV-10 varied from hypodiploid to hypotetraploid with a slowly rising mode in the hypertriploid range. The karyotype was unstable with mainly telomeric associations, di- and tricentric chromosomes, isochromosomes, and a decreasing number of cells exhibiting dmin. At passage 89 the karyotype was mainly hypertriploid (modal number 72, range 69 to 75) with a few cells hyperhexaploid and hyperdodecaploid. Consistent markers included two copies each of del(1)(q12q31) (M1) and der(9)t(1;9)(?;p22)

Figure 1 Karyotypes by R-banding of cell lines PZ-HPV-7 at passage 99 (A), and CA-HPV-10 at passage 89 (B). In (A), small chromosomal markers mainly composed of a centromere are marked as $c f$.
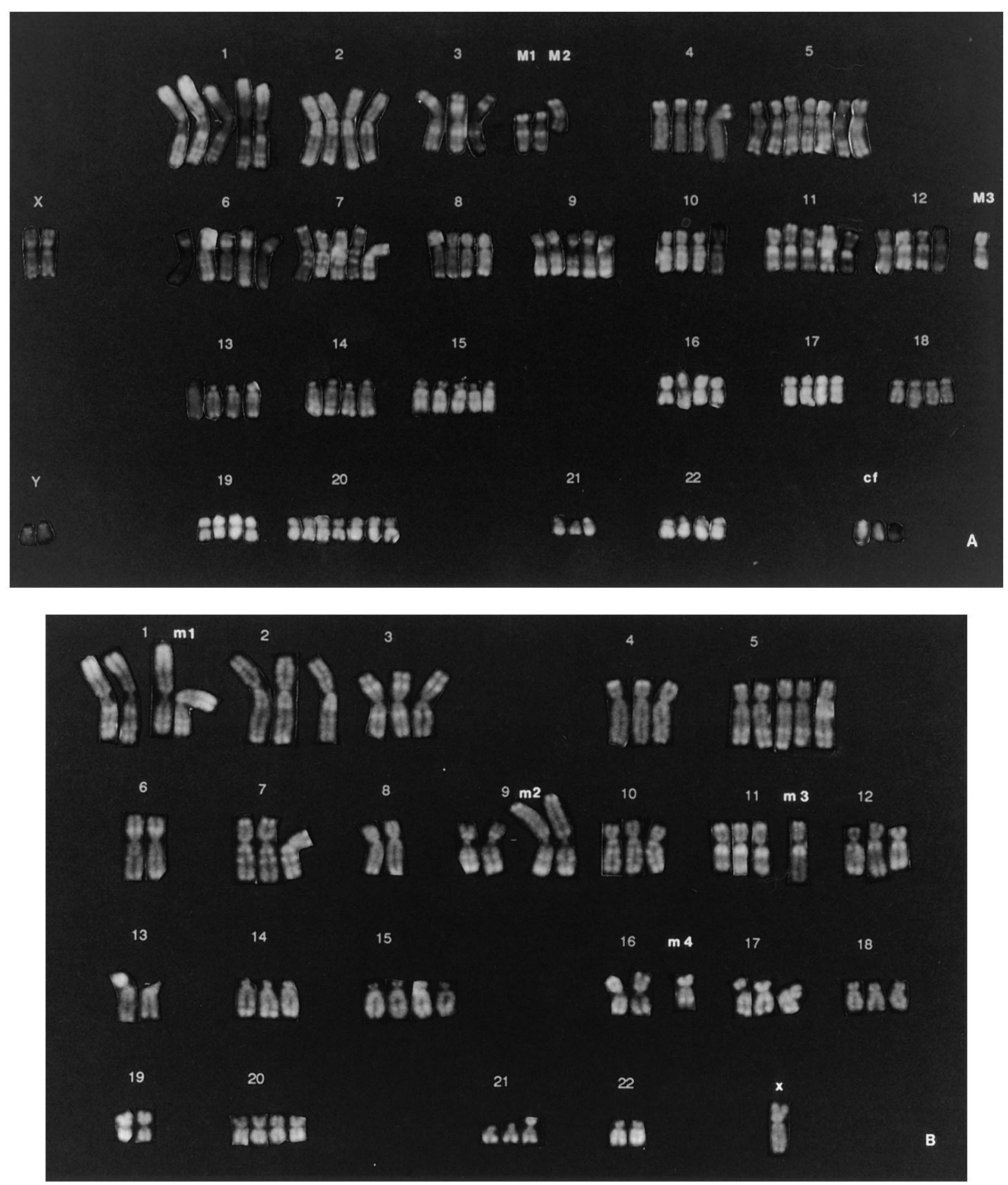
Table 1 FISH analysis of CA-HPV-10 (passage 89) using painting probes for chromosomes with numerical changes only ${ }^{a}$

\begin{tabular}{lc}
\hline Chromosome & Number of copies \\
\hline $\mathrm{Y}$ & 0 or 1 \\
$\mathrm{X}, 22$ & 2 \\
6,13 & 2 or 3 \\
$2,7,10,12,14,17,21$ & 3 \\
15 & 3 or 4 \\
20 & 4 \\
5 & 5 \\
\hline
\end{tabular}

${ }^{a}$ Eight metaphases analyzed per probe.

(M2) with probably a large hsr, one der(11)t(4;11)(?;q21) (M3) and one structurally abnormal der(16)(M4). Chromosomes 20 and 5 were overrepresented with an average of 4 and 5 copies, respectively. Loss of Y (0 to 1 copies), as well as the relative loss of chromosomes 6, 13 (2 to 3 copies), and 22 ( 2 copies) was remarkable. ure 1B shows the full karyotype of the CA-HPV-10 cell line in late passage as described above.

For identification of CA-HPV-10 markers, detailed FISH analyses were performed. In initial experiments DOP-PCRamplified flow-sorted chromosomes 4 and 9, and a commercially available chromosome 11 probe was used on metaphase spreads of cell line CA-HPV-10 (passage 89) to identify the $11 \mathrm{q}+$ and $9 \mathrm{p}+$ markers. These single chromosomal paints of chromosomes 4, 9, and 11, as well as cohybridization experiments of 4 and 11 revealed a der(11)t(4;11), whereas the hsr on 9p was investigated. Subsequently, for each chromosome, whole libraries were used as paints, sometimes in combination with specific centromeric probes. Eight to 31 metaphases were analyzed. Each paint showed numerical changes consistent with the cytogenetic findings (Table 1) as well as a number of marker chromosomes (Table 2). The $9 p+$ hsr is painted with chromosome 1 specific DNA, which is shown in Figure 2. In double staining experiments using loci-specific probes for 1p36, 1p32/ $2 q 23,2 q$, and 9p21, the hsr was studied in detail. However, none of these probes were located on the hsr. The studied probes exhibited an otherwise expected staining pattern on the respective chromosomes 1 and 2, whereas the 9p21 probe for the $p 16$ tumor suppressor gene revealed no deletion.

\section{FISH Analysis of HPV 18 Incorporation Sites}

Preparation of HPV 18 DNA specific probes was established using the original purified plasmid. Metaphase chromosomal spreads of Hela cells, containing several genomic copies of integrated HPV 18 DNA, were used as positive controls. At least 20 metaphases of each cell line were analyzed. Using the full HPV 18 plasmid as a probe, we obtained a strong hybridization signal in the HeLa cell line and a weak signal in our cell lines. The weaker signal was probably because of a low number of copies of the HPV 18 genome in the PZ-HPV-7 and CA-HPV-10 cell lines. Both cell lines showed single HPV type 18 genomic integration sites. For the PZ-HPV-7 cell line, the integration site was identified on 1p, whereas for the CA-HPV-10 cell line, it was identified on the $9 p+$ marker. The latter is

Table 2 FISH analysis of CA-HPV-10 (passage 89) using painting probes for chromosomes exhibiting numerical and structural changes

\begin{tabular}{|c|c|c|c|c|}
\hline \multirow{2}{*}{ 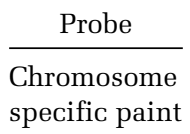 } & \multirow{2}{*}{$\begin{array}{l}\text { Number of } \\
\text { metaphases } \\
\text { analyzed }\end{array}$} & \multicolumn{2}{|c|}{ Chromosomes (partially) painted } & \multirow[b]{2}{*}{$\begin{array}{l}\text { Marker } \\
\text { designation }\end{array}$} \\
\hline & & $\begin{array}{l}\text { Number of } \\
\text { intact copies }\end{array}$ & Markers $^{a}$ & \\
\hline \multirow[t]{5}{*}{1} & 9 & 2 & $\operatorname{del}(1)(q 12 q 31) \times 2$ & (M1) \\
\hline & & & $\operatorname{add}(9)(\mathrm{p} 22) \times 2$ & (M2) \\
\hline & 7 & 3 & $\operatorname{del}(1)(q 12 q 31)$ & (M1) \\
\hline & & & $\operatorname{add}(9)(\mathrm{p} 22) \times 2$ & (M2) \\
\hline & & & marker (E size) & \\
\hline \multirow[t]{4}{*}{3} & 15 & 3 or 4 & & \\
\hline & 7 & 3 & marker (A size) & \\
\hline & 6 & 3 & marker (D size) & \\
\hline & 3 & 2 or 3 & marker (G size) & \\
\hline 4 & 8 & 2 or 3 & $\operatorname{der}(11) t(4 ; 11)(? ; q 21)$ & (M3) \\
\hline \multirow[t]{2}{*}{8} & 7 & 3 & & \\
\hline & 3 & 2 or 3 & $\operatorname{der}(16)$ & (M4) \\
\hline 9 & 8 & 2 & $\operatorname{add}(9)(\mathrm{p} 22) \times 2$ & (M2) \\
\hline \multirow[t]{2}{*}{11} & 5 & 3 & & \\
\hline & 16 & 2 or 3 & $\operatorname{der}(11) t(4 ; 11)(? ; q 21)$ & (M3) \\
\hline \multirow[t]{2}{*}{16} & 4 & 3 & & \\
\hline & 4 & 2 & $\operatorname{der}(16)$ & (M4) \\
\hline \multirow[t]{2}{*}{18} & 3 & 3 & & \\
\hline & 5 & 3 & small marker & \\
\hline \multirow[t]{2}{*}{19} & 4 & 2 or 3 & & \\
\hline & 4 & 2 or 3 & small marker & \\
\hline
\end{tabular}

${ }^{a}$ Markers are described by their appearance, DAPI banding and (partial) paint. (M1-4), markers indicated in karyotype (Fig. 1B). 

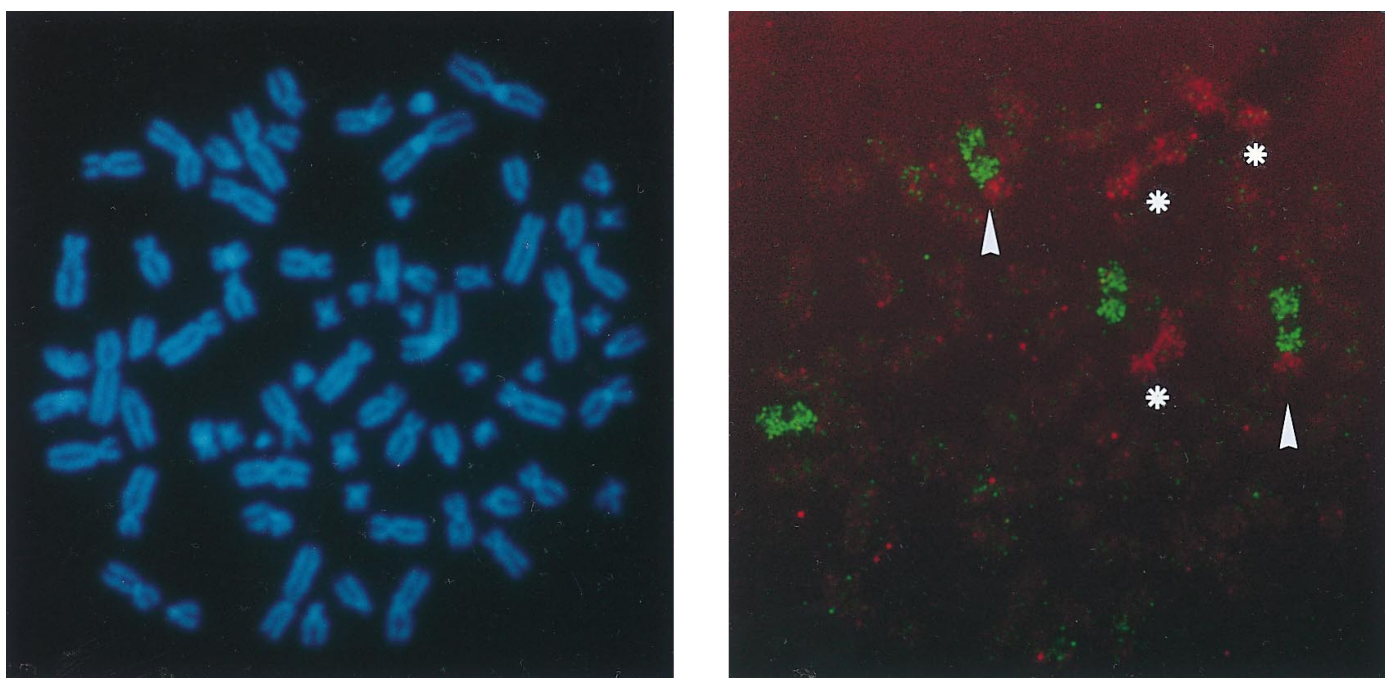

Figure 2 CA-HPV-10 cell line metaphase spread using DAPI counterstaining (left side) for chromosome identification and whole chromosome paints (right side) for 1 (staining red) and 9 (staining green). Two copies of the 9p+ hsr are stained with chromosome 1 specific DNA (arrowhead). Three copies of 1 are indicated with an asterix.

demonstrated in Figure 3 in a double staining experiment with the centromere 8 probe.

\section{DISCUSSION}

As a model for the study of prostate carcinogenesis, two epithelial cell lines, PZ-HPV-7 and CA-HPV-10, have been established using HPV type 18 DNA. Immortalization with the HPV type 18 genome was attempted because HPV DNA sequences have been detected in human prostatic tissues of different histologies [31-36], and the detected HPV DNAs were shown to be transcriptionally active [37], although the role of HPV in the prostate remains unclear [38]. Another reason to perform HPV transformation studies was to prolong the limited in vitro lifespan of human epithelial prostate cells per se, which had been accomplished previously using SV40 DNA [39-41]. The resulting cytogenetic changes were evaluated in the described analysis. The PZ-HPV-7 cell line, originating from a normal epithelial human prostate cell strain, was diploid and relatively unchanged at early (15 and 36) passage. PZHPV-7 progressed in culture to a modal number of 106 chromosomes with mostly numeric changes and only a few structural markers. In contrast, CA-HPV-10 showed a hypertriploid mode in both analyses of early and late passages, with a number of characteristic markers, which were not fully present in the earlier passages. Loss of chromosome 22 was of interest, because it was not observed in HPV immortalized keratinocyte cell lines [42] nor in HPV immortalized cell lines from other organ systems [39-42]. Furthermore, the relative gain of both chromosomes 5 and 20 in the two cell lines, PZ-HPV-7 and CA-HPV-10, was remarkable. This combination has not specifically been described before as an HPV transformation related phenomenon, although a gain of chromosome 20 has been reported [43-45].
After HPV transfection triploidization is rather commonly described as well as structural genomic rearrangements $[45,46]$. Also, single site HPV DNA integration was observed in cervical carcinoma cell lines [47]. HPV sequences of cervical carcinoma cell lines integrated on normal and abnormal chromosomes. The staining pattern of HPV 16 integration sites showed evidence of replication together with the heterochromatic regions of chromosomes 1, 9, and 16 [48]. Reznikoff et al. [44] showed how the initial genetic alterations may direct late genetic changes and

Figure 3 The HPV type 18 DNA integration site (green) of the CA-HPV-10 cell line is shown on 9p+ (arrowhead). In this experiment double staining with a centromere 8 probe was used to distinguish C sized chromosomes 8 and 9.

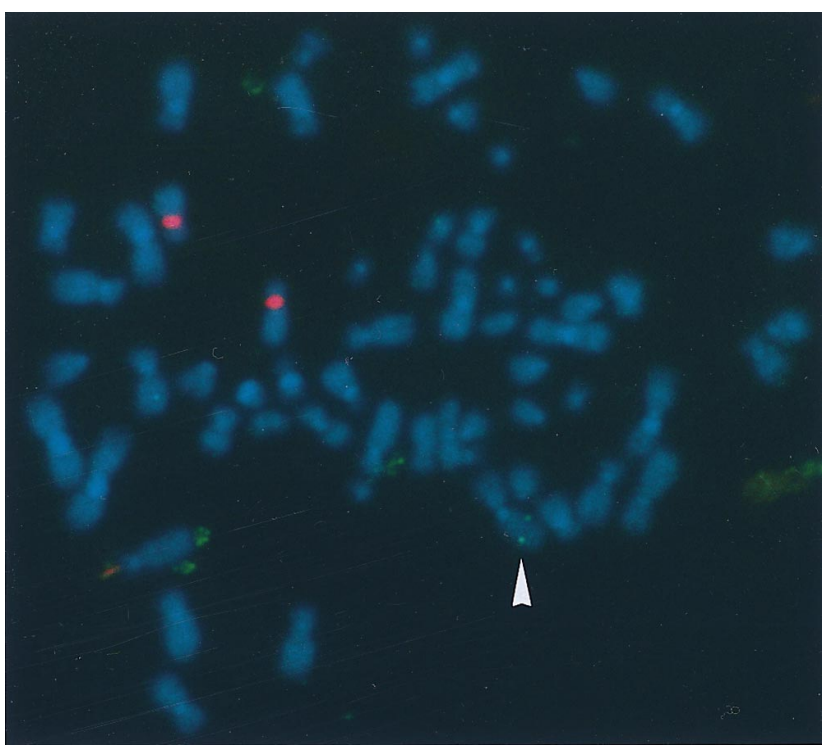


how different combinations of genetic alterations work together to block cellular senescence, initiate tumorigenesis, and lead to tumor progression in transitional cell carcinoma. After transfection of HPV type 16 E6, which represents one of the early gene regions involved in transformation, a specific association of $3 p$ loss with chromosome 9 instability was found. These karyotypic changes would seem to fit the general cytogenetic features of the PZ-HPV-7 and CAHPV-10 cell lines.

Loss of the Y chromosome is of interest in view of recent studies. Gains as well as deletions of the Y chromosome were found in prostatic carcinomas using in situ hybridization [10, 14-16]. Recently, loss of the Y-chromosome was found in metastatic prostate carcinoma specimen, whereas the primary carcinoma and adjacent prostatic intraepithelial neoplasia lesions did not show this deletion [15]. However, it is unclear whether this loss of the Y-chromosome is a relatively nonspecific or possibly significant cytogenetic correlate of progression in prostate cancer. It has been found in other urinary tract tumors $[49,50]$. Our findings could be significant although cytogenetic phenomena associated with the HPV immortalization should be considered. Relative marked loss of the Y chromosome was found in the cell line CA-HPV-10, which was derived from a high-grade adenocarcinoma precursor cell strain HSca, that had an extra Y chromosome before transfection [7]. The PZ-HPV-7 cell line did not show such a prominent loss of the chromosome.

In addition to an abnormal karyotype of $47, \mathrm{XY},+\mathrm{Y}$, the precursor cell strain of CA-HPV-10 contained dmin chromosomes. The presence of both dmin and hsr is suggestive of gene amplification events possibly representing oncogene amplification [51], as has been reported in other solid tumors [52, 53]. The cytogenetic evaluation with banding techniques of cell line CA-HPV-10 showed an hsr on chromosome 9p. Instead of a possible complex translocation, additional painting experiments revealed the configuration of a translocation, $\operatorname{der}(11) t(4 ; 11)(? ; q 21 r)$. The hsr on $9 p$ was studied using whole chromosome paints, which showed its chromosome 1 origin. The determination of HPV integration sites on $1 \mathrm{p}$ in the PZ-HPV-7 cell line and $9 p+$ in chromatin of 1 on the add(9)(p22) in the CA-HPV10 cell line does raise the question of whether there is a preferential integration site following HPV transfection in prostate epithelial cells. Using several loci specific probes, the $9 p+$ marker was targeted; however, because none were found to be located on the hsr, the conclusions from these experiments were limited. A probe for the $p 16$ tumor suppressor gene located on 9p21 [29] showed no deletion. The question of whether the hsr and dmin were retained in CA-HPV-10 or if they resulted from the HPV immortalization remains open. The formation of hsr as a reflection of DNA amplification has been described after HPV immortalization of keratinocytes [48]. Unfortunately, the original metaphase spreads of the CA-HPV-10 precursor HSca were not available for additional chromosomal painting, but it would seem appropriate to assume that the dmin and hsr of the CA-HPV-10 cell line have been retained from the precursor cell. Efforts to isolate these particular hsr and dmin using flow sorting techniques [20] have been unsuccessful because of the high viscosity of chromosome suspensions from these cells. Nevertheless, further studies for isolation of these aberrant chromosomal parts are warranted, because building a physical map of the involved regions could provide new insights of mechanisms involved in human prostate carcinogenesis.

The cytogenetic evaluation of PZ-HPV-7 and CA-HPV10 revealed several karyotypic abnormalities that can be of interest in the pursuit of a multistep in vitro model of human prostate carcinogenesis. The cytogenetic modifications that were identified represent a range of HPV transfection related phenomena within the residual pattern of the original karyotype.

We thank Bert J. Eussen for technical assistance with initial painting studies of CA-HPV-10 chromosomes 4, 9, and 11. This work was in part supported by grant IKR 90-12 from the Dutch Cancer Society.

\section{REFERENCES}

1. Lu-Yao GL, Greenberg ER (1994): Changes in prostate cancer incidence and treatment in USA. Lancet 343:251-254.

2. Schröder FH, Damhuis RAM, Kirkels WJ, De Koning HJ, Kranse R, Nijs HGT, Blijenberg BG (1996): European randomized study of screening for prostate cancer-the Rotterdam pilot studies. Int J Cancer 65:145-151.

3. Peehl DM (1992): Culture of human prostatic epithelial cells. In: Culture of Epithelial Cells. IA Freshney, ed. Wiley-Liss, New York, pp. 159-180.

4. Weijerman PC, König JJ, Wong ST, Niesters HGM, Peehl DM (1994): Lipofection-mediated immortalization of human prostate epithelial cells of normal and malignant origin using human papilloma virus type 18 DNA. Cancer Res 54:55795583.

5. Carter BS, Ewing CM, Ward WS, Treiger BF, Aalders TW, Schalken JA, Epstein JI, Isaacs WE (1990): Allelic loss of chromosomes $16 \mathrm{q}$ and $10 \mathrm{q}$ in human prostate cancer. Proc Natl Acad Sci USA 87:8751-8755.

6. Bergerheim US, Kunimi K, Collins VP, Ekman P (1991): Deletion mapping of chromosomes 8, 10 and 16 in human prostatic carcinoma. Genes Chromosom Cancer 3:215-220.

7. Brothman AR, Peehl DM, Patel AM, MacDonald GR, McNeal JE, Ladaga LE, Schellhammer PF (1991): Cytogenetic evaluation of 20 primary prostatic tumors. Cancer Genet Cytogen 55:79-84.

8. Sandberg AA (1992): Chromosomal abnormalities and related events in prostate cancer. Hum Pathol 23:368-380.

9. Bova GS, Carter BS, Bussemakers MJG, Emi M, Fujiwara Y, Kyprianou N, Jacobs SC, Robinson JC, Epstein JI, Walsh PC, Isaacs WB (1993): Homozygous deletion and frequent allelic loss of chromosome 8p22 loci in human prostate cancer. Cancer Res 53:3869-3873.

10. Baretton GB, Valina C, Vogt T, Schneiderbanger K, Diebold J, Löhrs U (1994): Interphase cytogenetic analysis of prostatic carcinoma by use of non-isotopic in situ hybridization. Cancer Res 54:4472-4480.

11. Bandyk MG, Zhao L, Troncoso P, Pisters LL, Palmer JL, Eschenbach AC von, Chung LWK, Liang JC (1994): Trisomy 7: a potential cytogenetic marker for human prostate cancer progression. Genes Chromosom Cancer 9:19-27.

12. Alcarez A, Takahshi S, Brown JA, Herath JF, Bergstralh EJ, Larson-Keller JJ, Lieber MM, Jenkins RB (1994): Aneuploidy and aneusomy of chromosome 7 detected by fluorescence in 
situ hybridization are markers of poor prognosis in prostate cancer. Cancer Res 54:3998-4003.

13. Visakorpi T, Kallioniemi AH, Syvänen A-C, Hyytinen ER, Karhu R, Tammela T, Isola JJ, Kallioniemi O-P (1995): Genetic changes in primary and recurrent prostate cancer by comparitive genomic hybridization. Cancer Res 55:342-347.

14. Alers JC, Krijtenburg PJ, Visser KJ, Bosman FT, van der Kwast TH, van Dekken H (1995): Interphase cytogenetics of prostatic carcinoma and precursor lesions: analysis of 25 radical prostatectomies and 17 adjacent prostatic intraepithelial neoplasias. Genes Chromosom Cancer 12:241-250.

15. Qian J, Bostwick DG, Takahshi S, Borell TJ, Herath JF, Bergstralh EJ, Larson-Keller JJ, Lieber MM, Jenkins RB (1995): Chromosomal anomalies in prostatic intraepithelial neoplasia and carcinoma detected by fluorescence in situ hybridization. Cancer Res 55:5408-5414.

16. König JJ, Teubel W, Romijn JC, Schröder FH, Hagemeijer A (1996): Gain and loss of chromosomes 1, 7, 8, 10, 18 and $Y$ in 46 prostate cancers. Human Pathol 27:720-727.

17. Cher ML, Bova GS, Moore DH, Small EJ, Caroll PR, Pin SS, Epstein JI, Isaacs WB, Jensen RH (1996): Genetic alterations in untreated metastases and androgen-independent prostate cancer detected by comparative genomic hybridization. Cancer Res 56:3091-3102.

18. Smith JR, Freije D, Carpten JD, Grönberg H, Xu J, Isaacs SD, Brownstein MJ, Bova GS, Guo H, Bujnovsky P, Nusskern DR, Damber J-E, Bergh A, Emanuelsson M, Kallioniemi OP, Walker-Daniels J, Bailey-Wilson JE, Beaty TH, Meyers DA, Walsh PC, Collins FS, Trent JM, Isaacs WB (1996): Major susceptibility locus for prostate cancer on chromosome 1 suggested by a genome-wide search. Science 274:1371-1374.

19. König JJ, Kamst E, Hagemeijer A, Romijn JC, Horeszewicz J, Schröder FH (1989): Cytogenetic characterization of several androgen responsive and unresponsive sublines of the human prostatic carcinoma cell line LNCaP. Urol Res 17:79-86.

20. Telenius H, Pelmear AH, Tunnacliffe A, Carter NP, Behmel A, Ferguson-Smith MA, Nordenskjöld M, Pfragner R, Ponder BAJ (1992): Cytogenetic analysis by chromosome painting using flow-sorted chromosomes. Genes Chromosom Cancer $4: 257-263$

21. Cooke HJ, Hindley J (1979): Cloning of human satellite III DNA: different components are on different chromosomes. Nucl Acids Res 6:3177-3179.

22. Alexandrov IA, Mitkevich SP, Yurof YB (1988): The phylogeny of human chromosome specific alpha satellites. Chromosoma 96:443-453.

23. Donlon T, Wyman AR, Mulholland J, Barker D, Bruns G, Latt S, Botstein D (1986): Alpha satellite-like sequences at the centromeres of chromosome \#8. Am J Hum Genet 39:A196.

24. Moyzis RK, Albright KL, Bartholdi MF, Cram LS, Deaven LL, Hildebrand CE, Joste NE, Longmire JL, Meyne J, Schwarzacher-Robinson T (1987): Human chromosome-specific repetitive DNA sequences: novel markers for genetic analysis. Chromosoma 95:375-386.

25. Waye JS, Creeper LA, Willard HF (1987): Organization and evolution of alpha satellite DNA from human chromosome 11. Chromosoma 95:182-188.

26. Devilee P, Cremer T, Slagboom P, Bakker E, Scholl HP, Hager HD, Stevenson AF, Cornelisse CJ, Pearson PL (1986): Two subsets of human alphoid repetitive DNA show distinct preferential location in the pericentric regions of chromosomes 13, 18 and 21. Cytogenet Cell Genet 41:193-201.

27. Waye JS, Willard HF (1989): Chromosome specificity of satellite DNAs: short- and long-range organization of a diverged dimeric subset of human alpha satellite from chromosome 3. Chromosoma 97:475-480.

28. Weeda G, van Ham HC, Masurel R, Westerveld A, Odijk H, de Wit J, Bootsma D, van der Eb AJ, Hoeijmakers JH (1990):
Molecular cloning and biological characterization of the human excision repair gene ERCC-3. Mol Cell Biol 10:25702581.

29. Kamb A, Gruis NA, Weaver-Feldhaus J, Lui Q, Harschman K, Tavtigian SV, Stockert E, Day RS, Johnson RE, Skolnick MH (1994): A cell cycle regulator potentially involved in genesis of many tumor types. Science 264:436-440.

30. Arnoldus EPJ, Wiegant J, Noordermeer IA, Wessels JA, Beverstock GC, Grosveld G, Van Der Ploeg M, Raap AK (1990): Detection of the Philadelphia chromosome in interphase nuclei. Cytogenet Cell Genet 54:108.

31. McNicol PJ, Dodd JG (1991): High prevalence of human papillomavirus in prostate tissues. J Urol 145:850-852.

32. Anwar K, Nakakuki K, Shiraishi T, Naiki H, Yatani R, Inuzuka M (1992): Presence of ras oncogene mutations and human papillomavirus DNA in prostate carcinomas. Cancer Res 52:5991-5996.

33. Rotola A, Monini D, Di Luca D, Savioli A, Simone R, Secchiero P, Reggiani A, Cassai E (1992): Presence and physical state of HPV DNA in prostate and urinary-tract tissues. Int J Cancer 52:359-365.

34. Ibrahim GK, Gravitt PE, Dittrich KL, Ibrahim SN, Melhus O, Anderson M, Robertson CN (1992): Detection of human papillomavirus in the prostate by polymerase chain reaction and in situ hybridization. J Urol 148:1822-1826.

35. Sarkar FH, Sakr WA, Li YW, Sreepathi P, Crissman JD (1993): Detection of human papillomavirus (HPV) DNA in human prostatic tissues by polymerase chain reaction (PCR). Prostate 22:171-180.

36. Terris MK, McNeal JE, Freiha FS, Stamey TA, Peehl DM (1996): Human papillomavirus detection by PCR in benign and malignant prostate tissue is dependent on the primer set utilized. J Urol 155:343A.

37. Dodd JG, Paraskevas M, McNicol PJ (1993): Detection of human papillomavirus 16 transcription in human prostate tissue. J Urol 149:400-403.

38. Cuzick J (1995): Human papillomavirus infection of the prostate. Cancer Surveys 23:91-95.

39. Kaighn ME, Roger RR, Lechner JF, Peehl DM, Camalier RF, Brash DE, Saffiotti U, Harris C (1989): Transformation of human neonatal prostate epithelial cells by strontium phosphate transfection with a plasmid containing SV 40 early region genes. Cancer Res 49:3050-3056.

40. Cussenot O, Berthon P, Berger R, Mowszowics I, Faille A, Hojman F, Teillac P, Le Duc A, Calvo F (1992): Immortalization of human prostatic epithelial cells by liposomes containing large T-SV40 gene. J Urol 143:881-886.

41. Lee MS, Garvenko E, Yun JS, Weijerman PC, Peehl DM, Chen LS, Rhim JS (1994): Characterization of adult human prostate epithelial cells immortalized by polybrene-induced DNA transfection with a plasmid containing an origin defective SV40-genome. Int J Oncol 4:821-830.

42. Seagon S, Dürst M (1994): Genetic analysis of an in vitro model system for human papilloma virus type 16-associated tumorigenesis. Cancer Res 54:5593-5598.

43. Swisshelm K, Leonard M, Sager R (1992): Preferential chromosome loss in human papilloma virus DNA-immortalized mammary cells. Genes Chromosom Cancer 5:219-226.

44. Reznikoff CA, Savelieva E, Belair C, Waldman F, DeVries S, Newton MA (1995): Different combinations of genetic alterations in TCC pathogenesis. Urol Res 23:254.

45. DiPaolo JA, Popescu NC, Alvarez L, Woodworth CD (1993) Cellular and molecular alterations in human epithelial cells transformed by recombinant human papillomavirus DNA. Crit Rev Oncogen 4:337-360.

46. Popescu NC, Zimonjic DB, Simpson S, Dipaolo JA (1995): Cumulative gene and chromosome alterations associated 
with in vitro neoplastic transformation of human cervical cells. Int J Oncol 7:279-285.

47. Dürst M, Dzarlieva-Petrusevska RT, Boukamp P, Fusenig NE, Gissmann L (1987): Molecular and cytogenetic analysis of immortalized human primary keratinocytes obtained after transfection with human papillomavirus type 16 DNA. Oncogene 1:251-256.

48. Popescu NC, DiPaolo JA (1990): Integration of human papillomavirus 16 DNA and genomic rearrangements in immortalized human keratinocyte lines. Cancer Res 50:1316-1323.

49. Kovacs G, Tory K, Kovacs A (1994): Development of papillary tumours is associated with loss of Y-chromosome-specific DNA sequences. J Pathol 173:39-44.

50. Brown JA, Takahashi S, Alcaraz A, Borell TJ, Anderl KL, Qian J, Persons DL, Bostwick DG, Lieber MM, Jenkins RB
(1996) : Fluorescence in situ hybridization analysis of renal oncocytoma reveals frequent loss of chromosomes $\mathrm{Y}$ and 1 . J Urol 156:31-35.

51. Limon J, Lundgren R, Elfving P, Heim S, Kristoffersson U, Mandahl N, Mitelman F (1989): Double minutes in two primary adenocarcinomas of the prostate. Cancer Genet Cytogenet 39:191-194.

52. Carroll SM, DeRose ML, Gaudray P, Moore CM, NeedhamVandevanter DR, Von Hoff DD, Wahl GM (1988): Double minute chromosomes can be produced from precursors derived from a chromosomal deletion. Mol Cell Biol 8:15251533.

53. Wolman SR, Henderson AS (1989): Chromosome aberrations as markers of oncogene amplification. Hum Pathol 20:308315. 